\title{
Production Rate Modelling towards Salt Consumption as a Solution to Avoid Hypothyroid Disease for Indonesian People
}

\author{
Glagah Eskacakra Setyowisnu*, Muhamad Rizky Febriawan, Ai Aas Siti Asiyah, \\ Nisa Uswatun Khasanah, Prihantini \\ Mathematics, Faculty of Mathematics and Natural Science, Yogyakarta State University Yogyakarta, \\ Email*: glagah.eskacakra2016@student.uny.ac.id
}

\begin{abstract}
Salt is one of the essential ingredients that is very important for all people. The use of salt has never been separated from everyday life by all corners of the world, including Indonesia. The Indonesian people's need for salt reaches a high enough number that there has never been a shortage of salt. This certainly can be a problem in meeting the basic needs of the Indonesian people and impacting on public health, iodine deficiency which causes hypothyroid disease. From this case, this study aims to model the rate of salt production with the consumption rate momentum among the people. This mathematical model is constructed from one of Newton's new laws of motion, 3rd Newton's Law with several assumptions and ignores the human factor in production. The results of the model will be analyzed and determined the best solution to overcome the shortage of salt available in Indonesia.
\end{abstract}

Keywords: Mathematical Modeling, $3^{\text {rd }}$ Newton's Law, Momentum.

\section{INTRODUCTION}

Salt is one of the inseparable food ingredients in human life in modern times, including Indonesian people. Besides being used as a food ingredient, in Indonesia, salt is also used as a raw material and auxiliary materials in the chemical industry such as pharmaceuticals, textiles, soap, etc. However, population growth can have an impact on increasing people's need for salt.

Indonesia is a country with a coastline of 99,093 kilometers and is the second longest in the world, so it possible for Indonesia to produce enough salt because it produces ionic material dissolved in the sea. But in the end, only a bit was made as locations for salt ponds. This makes its production in Indonesia is not balanced with the needs of the Indonesian people for salt. Furthermore, the air humidity in Indonesia reaches $80 \%$ and it makes manual evaporation in salt ponds run slowly and can also reduce the quality of salt content. Another factor is the unit cost of production in the salt industry is pretty high in Indonesia. This was triggered by manual production methods and the use of seasonal land, so the production time is short with low quantity.

The Coordinating Ministry for Economic Affairs mentioned that the total national salt production in 2019 expected to increase $14.4 \%$ to 2.3 million tons compared to 2018 salt production which reached 2.7 million tons. Low domestic salt production makes the government imports salt for the people's need. Whereas in 2019 the national salt demand is estimated to reach 4.2 million tons. Therefore, the government allocates salt import in 2019 to 2.72 million tons compared to 2018 of 2.71 million tons. To satisfy the needs for salt, of course the increase in salt production must be directly proportional to the increase in Indonesia's population. If this does not work, then salt scarcity in Indonesia cannot be canceled.

One of the ways to calculate the rate of salt production against the rate of consumption by the people of Indonesia is making a mathematics model using Newton's Law III. Knowing that shifting salt production to its consumption rate can become a reference for government policy to take the right steps in harmonizing the salt production and its consumption rate. So, the production and consumption rate will be balanced. So, hopefully after the model is formed, the results of the model will be the good solution to overcome the shortage of salt available in Indonesia.

\section{MATERIALS AND METHODS}

\section{Production}

According to Drs. Eko Harsono (1994:4) that production is any human effort or activity that brings things into a state that can be better used for human needs. Meanwhile according to Drs. Mohamad Hatta (1994: 4), production is all the work which gives rise to the use, is expanded to the existing use and is expanded to the use between the people.

\section{Consumption}

According to Suherman Rosyidi (1996), consumption is defined as the use of goods and services that will directly meet human needs. Consumption or more precisely personal consumption expenditure is expenditure by households on final goods and services. 


\section{Mathematical modeling}

According to Prayudi (2006), mathematical modeling is a field of mathematics that seeks to present and explain the physical systems or problems in the real world in a mathematical statement in order to obtain an understanding of real-world problems have been more appropriate.

\section{Newton's $3^{\text {rd }}$ law}

The identical value of force but have the opposite direction and working on different objects, if an object is to get force, then the object would send force equal to the force provider, or it can be said in the opposite direction to the applied force. The equation: $F_{\text {action }}=$ $-F_{\text {reaction }}$.

\section{Force $(\boldsymbol{F})$}

Force is a push or a pull that can cause a mass of changes, both in direction and geometric constructions.

\section{Mass ( $m$ )}

The mass of a body is a measure of the amount of the substance contained in the object.

\section{Velocity (v)}

Velocity is a vector quantity that indicates how far the object moves each unit of time.

\section{Momentum (p)}

The momentum of a particle can be regarded as a measure of the difficulty to mute objects and the quantity that is proportional to the mass $(\boldsymbol{m})$ and speed $(\mathbf{v})$ so it can be written $\boldsymbol{p}=\boldsymbol{m}$. $\boldsymbol{v}$

\section{Acceleration (a)}

Acceleration is the change in velocity that occurs on an object each unit of time.

\section{RESULTS AND DISCUSSION}

\section{Assumptions}

The assumption used to make this model is

1. Number of producers influencing the model

2. Manufacturer profits are ignored

3. Human factors are static

4. Closed Population

5. Request for salt $=P_{1}=m_{1} v_{1}$ and supply for salt $=$ $P_{2}=m_{2} v_{2}$

6. The amount of salt consumption $=m_{1}$ and the amount of salt production $=m_{2}$

7. The rate of salt consumption $=v_{1}$ and the rate of salt production $=v_{2}$

8. After steps 1) and 2) there is no static anymore
The resulting mathematical model

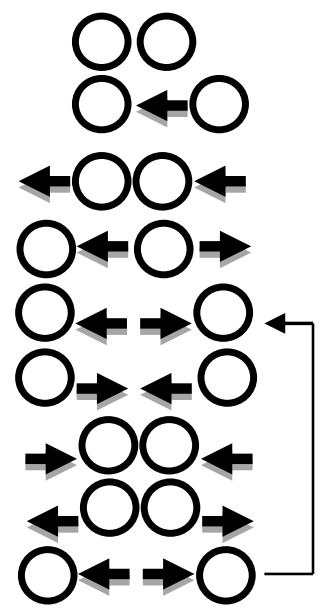

Figure 1. Supply and Demand Flow Models until Stable

\section{CONCLUSION}

Indonesian people's need for salt reaches a high enough number that there has never been a shortage of salt. This certainly can be a problem in meeting the basic needs of the Indonesian people and impacting on public health, iodine deficiency which causes hypothyroid disease. From this case, this study aims to model the rate of salt production with the consumption rate momentum among the people. This mathematical model is constructed from one of Newton's new laws of motion, 3rd Newton's Law with several assumptions and ignores the human factor in production. The results of the model will be analyzed and determined the best solution to overcome the shortage of salt available in Indonesia.

\section{REFERENCES}

Tansil, Y., Belina, Y., \& Widjaja, T. 2016. Produksi Garam Farmasi dari Garam Rakyat. Jurnal Teknik ITS 5(2): 80-84.

Adiraga, Y., \& Setiawan, A.H. 2014. Analisis Dampak Perubahan Curah Hujan, Luas Tambak Garam dan Jumlah Petani Garam terhadap Produksi Usaha Garam Rakyat di Kecamatan Juwana Kabupaten Pati Periode 2003-2012. Diponegoro Journal of economics 3: 1-13.

Saharjo BH, Nurhayati AD. 2006. Domination and composition structure change at hemic peat natural regeneration following burning; a case study in Pelalawan, Riau Province. Biodiversitas 7: 154-158.

Fraderick J, Bueche,Ph.D., 2006. Fisika Universitas Edisi Kesepuluh. Erlangga, Surakarta.

Hasan, T. I. (2011). Identifikasi Sosial Ekonomi dan Ketenagakerjaan Petani Garam di Kabupaten Bireuen. Journal Sains Riset Vol 1 - No. 2, 2011, 2-3. 